\title{
The chemokine receptor 7 regulates cell adhesion and migration via $\$ 1$ integrin in metastatic squamous cell carcinoma of the head and neck
}

\author{
PENG LI ${ }^{1,2}$, ZHEN-JIN ZHAO $^{3}$, FA-YU LIU $^{1,2}$, LI-YAN SUN ${ }^{3}$, XUE DING $^{1,2}$, \\ WEN-ZHONG ZHANG ${ }^{1,2}$, DE-HAO SHANG ${ }^{1,2}$ and CHANG-FU SUN ${ }^{1,2}$ \\ Departments of ${ }^{1}$ Oromaxillofacial-Head and Neck Surgery, ${ }^{2}$ Oral Maxillofacial Surgery, ${ }^{3}$ Orthodontics, \\ School of Stomatology, China Medical University, No. 117. Nanjing Bei Jie, \\ Heping District, Shenyang, Liaoning 110002, P.R. China
}

Received May 4, 2010; Accepted June 28, 2010

DOI: 10.3892/or_00000946

\begin{abstract}
Migration and adhesion of tumor cells are essential prerequisites for the formation of metastases in malignant diseases. Chemokine receptor 7 (CCR7) has been shown to regulate integrin which can then facilitate adhesion of cancer cells to and/or migration through the extracellular matrix (ECM). In order to identify the connection between CCR7 and $\beta 1$ integrin, and the influence on cell adhesion and migration in metastatic squamous cell carcinoma of the head and neck (SCCHN). We use adhesion assays, migration assay, immunofluorescence staining, Western blotting, and immunohistochemical analysis to find whether $\beta 1$ integrin can be activated by CCL19 (CCR7's ligand) and its role in SCCHN. The experiments were performed in the metastatic SCCHN cell line PCI-37B after pre-incubation of the cells with CCL19 and B1 integrin inhibitors RGD-peptide. Our results demonstrate that CCR7 favours PCI-37B cell adhesion and migration, and induces reorganization of the actin cytoskeleton and up-expression of $\beta 1$ integrin protein. $\beta 1$ integrin inhibitor RGD-peptide can block all these effects. Taken together, our data indicate that CCR7 regulate cell adhesion and migration via $\beta 1$ integrin in metastatic SCCHN, and these results can provide a basis for new strategies in preventing metastases of SCCHN.
\end{abstract}

\section{Introduction}

SCCHN, a malignant tumor of epithelial origin, represents $>90 \%$ of all head and neck cancers (1). The 5-year survival rate is only $30-40 \%$ in $\mathrm{SCCHN}$, the mainly reasons are invasion and metastasis, especially metastasis to lymph node, lung,

Correspondence to: Dr Chang-Fu Sun, Department of Oromaxillofacial-Head and Neck Surgery, School of Stomatology, China Medical University, No. 117. Nanjing Bei Jie, Heping District, Shenyang, Liaoning 110002, P.R. China

E-mail: cfsun@mail.cmu.edu.cn

Key words: CCR7, 31 integrin, squamous cell carcinoma of head and neck, adhesion, migration liver and bone. The mechanisms leading to SCCHN metastasis are incompletely understood. No significant increase in the long-term survival rate has been achieved during the past 30 years, even through substantial improvements in the diagnosis of, local management of, and chemotherapy for SCCHN (2).

Chemokines are a superfamily of small chemoattractant cytokines that mediate their effects by binding to G-proteincoupled receptors, and initially characterized by their ability to induce migration of leukocytes. Chemokines are classified into 4 highly conserved groups: CXC, CC, C, and CX3C, based on the position of the first two cysteines adjacent to the amino terminus. The CC chemokine receptor 7 (CCR7) and its two ligands: CCL19 and CCL21, are thought to play a central role in regulating migration of lymphocytes to lymph nodes, such as in mature dendritic cells (DCs) (3), T and B cells (4). Because both metastasis and normal migration of leukocytes involve site-directed movement across vascular barriers, non-small cell lung cancer $(5,6)$, gastric carcinoma (7), colorectal carcinoma (8) and SCCHN $(1,2,9,10)$ cells also use chemokine-mediated mechanisms during the metastatic process (11).

Recently, a new role was described for chemokine family: signalling via chemokine receptors can modulate tumor cell expression of integrins which can then facilitate adhesion of cancer cells to and/or invasion through ECM. Chemokines can trigger rapid $\alpha 4 \beta 1$ integrin-dependent lymphocyte arrest to vascular endothelium (12). CXCR4 triggers integrin-related intracellular signaling and engagement modifies $\alpha 4 \beta 1$ integrindependent adhesion of renal carcinoma cells (1). CCL21 promotes the migration and adhesion of highly lymph node metastatic human non-small cell lung cancer via $\beta 1$ integrin (14). Binding of the chemokine CCL1/CCL21 to its receptor CCR7 through integrin increases adhesive properties of human mesangial cells (15). CCR7 and $\alpha 4 \beta 1$ integrin are important for migration of chronic lymphocytic leukemia cells into lymph nodes (16). It has been reported that this integrin-mediated adhesion of lymphocytes was induced by CCL21 and that the adhesion regulated the migration of lymphocytes to the lymph node (14).

Since the present data suggest that the $\beta 1$ integrin activated by CCR7 has function on adhesion and migration of DCs (3), lymphocytic leukemia cells $(4,12,16)$, renal 
carcinoma cells (13), non-small cell lung cancer (14), thyroid carcinoma cells (17), breast carcinoma cells (11), we hypothesized that CCR7 may regulate cell adhesion and migration via $\beta 1$ integrin in SCCHN. This study was designed to find out whether $\beta 1$ integrin can be activated by CCR7 and its role in adhesion and migration in metastatic SCCHN.

\section{Materials and methods}

SCC cell lines in the head and neck. Metastatic SCCHN cell lines PCI-37B of the head and neck, which express CCR7 strongly, were supplied by the University of Pittsburgh Cancer Institute, USA. PCI-37B were cultured as described previously (18) in Dulbecco's modified Eagle's medium (DMEM) (Invitrogen, Carlsbad, CA, USA), supplemented with $10 \%$ fetal bovine serum (FBS) (Gibco, Carlsbad, CA, USA), $100 \mathrm{U} / \mathrm{ml}$ penicillin $\mathrm{G}$, and $100 \mathrm{U} / \mathrm{ml}$ streptomycin. The cells were cultured in an atmosphere of $95 \%$ air $/ 5 \%$ $\mathrm{CO}_{2}$ at $37^{\circ} \mathrm{C}$.

Antibodies and reagents. CCL19 and CCR7-specific monoclonal antibody (mouse anti-human CCR7 antibody), B1 integrin, Albumin from bovine serum (BSA), and Fibronectin $(\mathrm{FN})$, were purchased from R\&D System (Minneapolis, MN, USA). Integrin inhibitor RGD (Arg-Gly-Asp) peptide, Rhodamine labed phalloidin, 3-(4,5-dimethyl-2-tetrazolyl)2,5-diphenyl-2H tetrazolium bromide (MTT), and dimethyl Sulfoxide (DMSO) was purchased from Sigma (St. Louis, MO, USA). Matrigel ${ }^{\mathrm{TM}}$ Basement Membrane Matrix was purchased from BD Bioscience PharMingen (Rockville, MD, USA).

Cell adhesion and MTT assays. Cell adhesion assays were performed in 96-well plates (Corning Costar, Cambridge, MA, USA) coated with BSA, Matrigel, fibronectin, or left uncoated. The plates were incubated at room temperature overnight, BSA as the contrast basement. To evaluate optimal conditions for RGD peptide density and time for the adhesion effects on adhesion of PCI-37B cells, PCI-37B cells treated with or without RGD-peptide in different concentration or for different time, followed by CCL19, and were plated in the 96-well plates in increasing cell number. Then washed with phosphate-buffered saline (PBS) three times. MTT (20 $\mu 1$, $5 \mu \mathrm{g} / \mathrm{ml}$ ) were added for $4 \mathrm{~h}$, then dimethyl sulphoxide (DMSO, Sigma, USA) was added to each well to lyse all cells for $1 \mathrm{~h}$ at $37^{\circ} \mathrm{C}, 5 \% \mathrm{CO}_{2}$. The optical density (OD) was read on a spectrometer (Sunrise, RC, Tecan, Switzerland) through a 490-nm filter. For each experimental condition 8 wells were analyzed in parallel.

Adhesion index $(\%)=[($ Matrigel or $\mathrm{FN}$ conditions cell OD/BSA conditions cell OD)-1] x 100\%.

Cell migration assay. The migration was assayed in transwell filter insert chambers ( $8 \mu \mathrm{m}$ pore size; Corning Costar) as described $(3,14)$. CCL19 (finally density is $500 \mathrm{ng} / \mathrm{ml}$ ) was placed in the lower wells. PCI-37B cells treated with or without RGD-peptide in different concentration or for different times at $37^{\circ} \mathrm{C}, 5 \% \mathrm{CO}_{2}$, were removed from the culture flasks and added to the upper chamber. After $60 \mathrm{~min}$ at $37^{\circ} \mathrm{C}$, cells on the upper surface of the transwell membrane were wiped off gently with cotton swabs. The lower surface of the filters were fixed with methanol and stained with hematoxylin. Cells migrated to the lower surface were counted under a microscope (Nikon TE2000-S Eclipse, Tokyo, Japan) at x200 magnification. For each experimental condition 4-5 wells were analyzed in parallel.

Immunofluorescence staining. PCI-37B cells were cultured using 24-well plates (Corning Costar). A total of 70-80\% confluent cells were starved of serum for $24 \mathrm{~h}$, then treated with or without RGD peptide for $4 \mathrm{~h}$, followed by CCL19 (finally density is $500 \mathrm{ng} / \mathrm{ml}$ ) for $30 \mathrm{~min}$ at $37^{\circ} \mathrm{C}, 5 \% \mathrm{CO}_{2}$. The cells were fixed in $2.5 \%$ glutaraldehyde for $10 \mathrm{~min}$, lysed in $0.1 \%$ Triton $\mathrm{X}-100$ for $5 \mathrm{~min}$ at $37^{\circ} \mathrm{C}$. Then incubated overnight at $37^{\circ} \mathrm{C}$ with the primary anti-bodies: $\beta 1$ integrin (1:100), and stained by Rhodamine-phalloidin for $30 \mathrm{~min}$. PBS washed three times during the two steps stated above. The cell morphology was analyzed by inverted microscope at x400 magnification. For each experimental condition 4-5 wells were analyzed in parallel.

Western blotting. PCI-37B cells were treated with and without the inhibitors RGD-peptide and CCR7 mAb, followed by CCL19. Whole cells were harvested in lysis buffer, containing sodium diphosphate, sodium tri-vanadium oxygen, Trishydrochloric acid, 1\% Triton X-100, protease and phosphatase inhibitors. Then lysates were centrifuged at $4^{\circ} \mathrm{C}$, $14,000 \mathrm{rpm}$, for $30 \mathrm{~min}$ after sonicated for $3 \mathrm{sec}$. Protein concentration of the lysate was determined by Bio-Rad protein assay dye reagent (Bio-Rad laboratories, Richmond, CA, USA). Then proteins were size-fractionated on $10 \%$ sodium dodecyl sulfate-polyacrylamide gel electrophoresis (SDSPAGE) and transferred to nitrocellulose filters by semi-dry blotting. The filter was blocked in PBS containing $1 \%$ skim milk, $0.1 \%$ Triton $\mathrm{X}-100$, sodium chloride and Tris [tris (hydroxymethyl)aminomethane] overnight at $4{ }^{\circ} \mathrm{C}$. The membrane was incubated with following 1/1000 diluted rabbit antibody $B 1$ integrin for $1 \mathrm{~h}$ at room temperature, and incubated with horseradish peroxidase-conjugated secondary antibodies (goat anti-rabbit, Sigma). Immune complexes were visualized using enhanced chemiluminescence (ECL) (Amersham Pharmacia Biotech, Piscataway, NJ, USA). Quantification of the signals was done by scanning densitometry using FluoroChem software (Version 2.0). $\beta$-actin (1:1000) served as the internal control.

Immunohistochemical analysis. Seventy-eight specimens of SCCHN tumors with the adjacent metastatic (or normal) lymph nodes and 10 specimens of normal human oral mucosal tissue were obtained from Head and Neck Tumor Center, School of Stomatology, China Medical University. All the specimens were obtained with the consent of the patients before surgery and in accordance with Health Insurance Portability. The classification of SCCHN, including primary tumors $(\mathrm{T})$, regional lymph nodes $(\mathrm{N})$, distant metastasis (M) and stage grouping, was determined according to the rules of the International Union Against Cancer (UICC) for Head and Neck Cancer (Tumor node metastasis, TNM classification, 1997). Immunohistochemical staining used conventional horseradish peroxidase immunohistochemical 
A

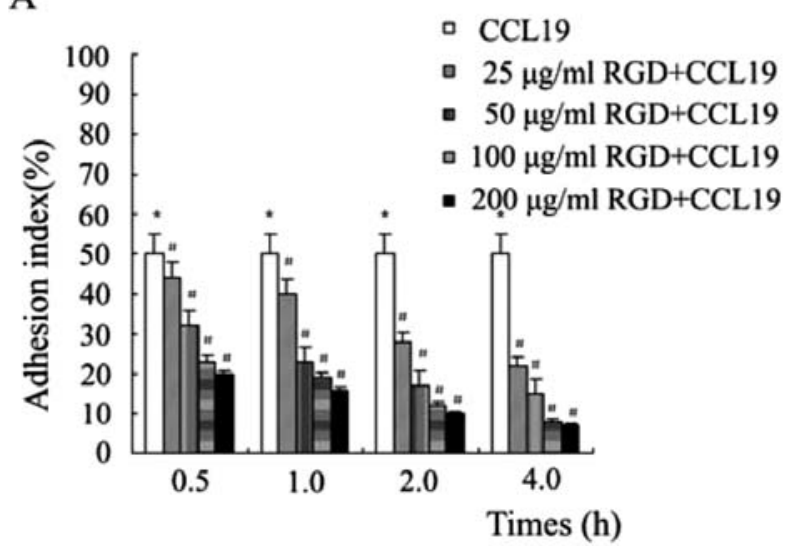

B

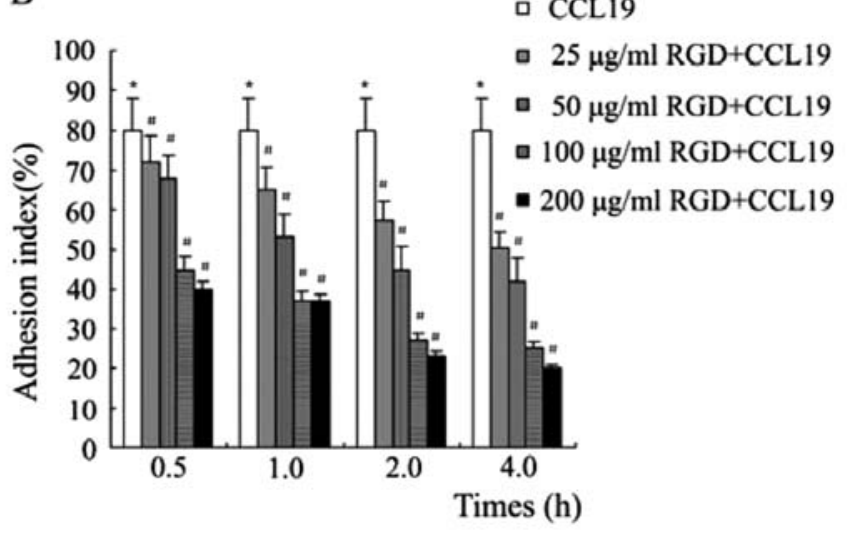

Figure 1. CCL19-induced and RGD-peptide blocked adhesion of PCI-37B cells. PCI-37B cells (8x104 cells/well) were plated in 96-well plates Matrigel (10 $\mathrm{mg} / \mathrm{ml})(\mathrm{A})$ and $\mathrm{FN}(\mathrm{B})(50 \mu \mathrm{g} / \mathrm{ml})$, and BSA $(10 \mathrm{mg} / \mathrm{ml})$ as the contrast basement. Different RGD-peptide density $(25-200 \mu \mathrm{g} / \mathrm{ml}) \mathrm{was}$ used for different times $(0.5,1,2$ and $4 \mathrm{~h}$ ) and then CCL19-induced $(500 \mathrm{ng} / \mathrm{ml}$ for $30 \mathrm{~min})$, were compared to CCL19-induced (500 ng/ml for $30 \mathrm{~min})$ and control. The results shown are representative for three independent experimental series. ${ }^{*} \mathrm{P}<0.05$ compared to untreated group, and ${ }^{\#} \mathrm{P}<0.05$ compared with the CCL19 group in both pre-coated Matrigel group (A) and pre-coated FN group (B) by paired Student's t-test.

staining methods. In brief, $5-\mu \mathrm{m}$ sections of the specimens were deparaffinized and hydrated with $0.6 \% \mathrm{H}_{2} \mathrm{O}_{2}$ in methanol to inhibit endogenous peroxidase, performed antigen retrieval and incubated with normal blocking serum for $10 \mathrm{~min}$. Then the sections were incubated with primary antibodies (1:100): CCR7-specific monoclonal antibody and $B 1$ integrin overnight at $4^{\circ} \mathrm{C}$. Immunodetection was performed using peroxidase labeled secondary antibody (R\&D System, Minneapolis, MN, USA) and diaminobenzidine for visualization. All the sections were counterstained with hematoxylin (Sigma). Negative controls included omission of the primary antibody. The cell morphology was analyzed by microscopy (Nikon Eclipse 80i, Tokyo, Japan) at x100-400 magnification. According to the percentage of positive tumor cells, all these cells were scored as negative $(-)(<10 \%$ or no staining); weak positive $(+)(11-50 \%)$; positive $(++)(51-75 \%)$; or strongly positive $(+++)(>75 \%)$.

Statistical analysis. All experiments were repeated 3-6 times. Values are provided as mean (SD) of repeated assays. Correlation between CCR7 and $B 1$ integrin expressions in specimens was analyzed by Spearman's test and $\chi^{2}$ test. $\mathrm{P}$-values were calculated by paired Student's t-test and the differences with $\mathrm{P}<0.05$ were considered to be significant. All statistical analyses were made with the help of the Statistical Package for the Social Sciences (SPSS Inc, Chicago, USA).

\section{Results}

CCL19 triggers $\beta 1$ integrin-dependent adhension of PCI-37B cells and RGD-peptide blocks it. To evaluate if CCL19 has an effect on PCI-37B cell adhesion we analyzed time- and dose-dependent effects on PCI-37B cells adhesiveness in pre-coated Matrigel group (Fig. 1A) and pre-coated FN group (Fig. 1B). In this study, we examined CCL19-induced activation of $\beta 1$ integrin that significantly enhanced the Adhesion index in SCCHN. RGD-containing peptides competitively combine with the binding site of $\beta 1$ integrin.
As shown in our study, the Adhesion index was effectively blocked by the integrin inhibitor RGD-peptide. Both in precoated Matrigel group and pre-coated FN group, the Adhesion index reduced with RGD-peptide densities increased with the different times studied. Adhesion index of the two groups was obviously different. $\mathrm{P}<0.05$, compared with pre-coated Matrigel group by paired Student's t-test.

CCL19-induces and RGD-peptide blocks migration of PCI$37 B$ cells. We next addressed whether $B 1$ integrin is required for the migration of SCCHN cells toward CCL19. Conditioned medium of CCL19 was placed on the lower part of a transwell unit, and PCI-37B cells were added to the upper part in the absence or presence of RGD-peptide. As shown in (Fig. 2), CCL19 significantly enhanced the migration ability of PCI-37B cells that could be specifically blocked by the RGD-peptide. The inhibitive ability became stronger with the RGD-peptide density increasing, but there was no sharp difference between 100 and $200 \mu \mathrm{g} / \mathrm{ml}$ RGD peptide.

CCL19-induces and RGD-peptide blocks reorganization of the actin cytoskeleton of PCI-37B. Reorganization of the actin cytoskeleton is an early event in the migratory response to chemokines (17). We examined rhodamine-labed phalloidin staining by invert microscopy, to investigate whether actin polymerization could be observed in response to CCL19, and the relationship with 31 integrin. After $1 \mathrm{~h}$ of CCL19 stimulation (Fig. 3), increased actin polymerization and the formation of cell extensions resembling filopodia were observed. These changes were inhibited in the presence of RGD-peptide.

$\beta 1$ integrin phosphorylation can be activated by CCL19 and blocked by RGD-peptide. The expression of overall and phosphorylated $\beta 1$ integrin was determined by Western blot analysis and quantified by computer-aided densitometry. As shown in Fig. 4, CCL19-induced B1 integrin activation to concentrations of 2 -fold of the baseline in PCI-37B cell line, which was calculated by incubation with media alone. 
A

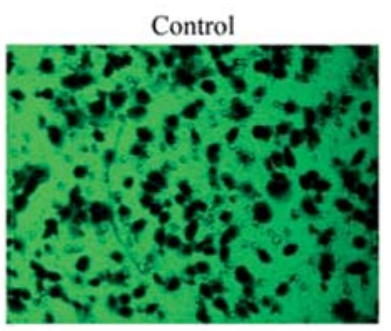

$25 \mu \mathrm{g} / \mathrm{ml}$ RGD $+\mathrm{CCL} 19$

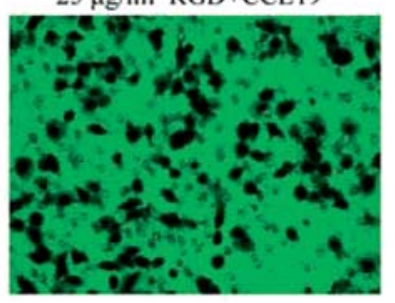

$100 \mu \mathrm{g} / \mathrm{ml} \mathrm{RGD}+\mathrm{CCL} 19$

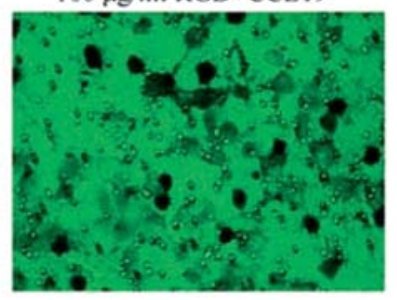

CCL19

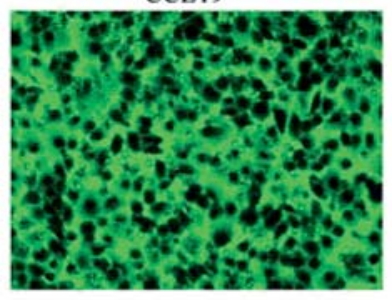

$50 \mu \mathrm{g} / \mathrm{ml}$ RGD + CCL 19

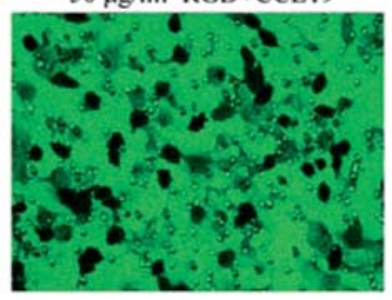

$200 \mu \mathrm{g} / \mathrm{ml} \mathrm{RGD}+\mathrm{CCL} 19$

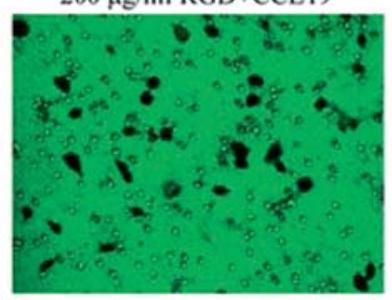

B

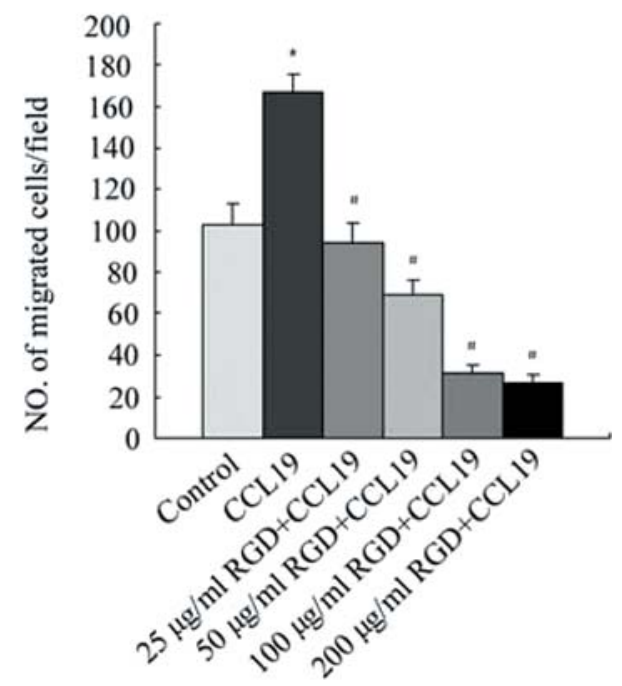

Figure 2. CCL19-induced and RGD-peptide blocked migration of PCI-37B cells. PCI-37B cells ( $2 \times 10^{5}$ cells/100 $\left.\mu 1\right)$ treated with different RGD-peptide density $(25-200 \mu \mathrm{g} / \mathrm{ml})$ for $4 \mathrm{~h}$ and CCL19: $500 \mathrm{ng} / \mathrm{ml}$ for $30 \mathrm{~min}$ ) compared with CCL19-induced (500 ng/ml for $30 \mathrm{~min}$ ) and control. Cells were counted under a microscope at x200 magnification (A). Results shown are representative for a series of three independent experiments. P<0.05, compared CCL19untreated control (B). Different RGD-peptide density blocked migration of PCI-37B, P<0.05, compared CCL19-induced group calculated by paired Student's t-test.
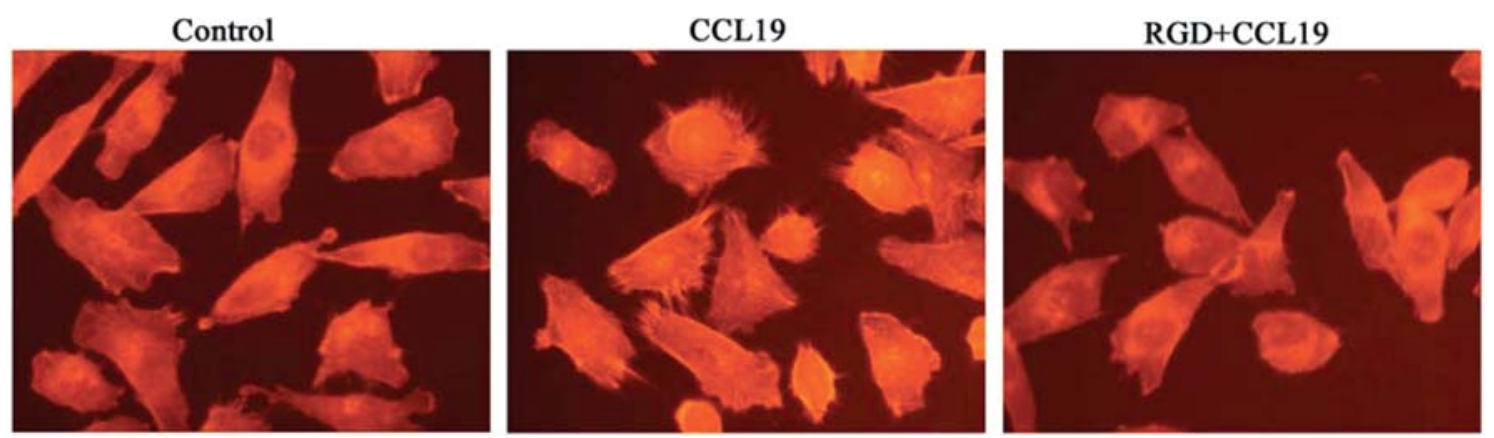

Figure 3. CCL19-induced and RGD-peptide blocked reorganization of the actin cytoskeleton of PCI-37B cells. CCR7 activation leads to actin polymerization and formed filopodia, RGD-peptide blocked this phenomenon in SCC of head and neck. PCI-37B cells were control, treated CCL19 (500 ng/ml) for $1 \mathrm{~h}$, or treated RGD-peptide $(100 \mathrm{mg} / \mathrm{ml})$ for $4 \mathrm{~h}$ and CCL19 $(500 \mathrm{ng} / \mathrm{ml})$ for $1 \mathrm{~h}$. The cells were stained by Rhodamine-labelled phalloidin, and show a considerable increase in actin polymerization and cell extensions resembling filopodia via CCL19 induction; these effects were blocked by RGD-peptide.

The phosphorylation of this was diminished by CCR7 mAb, which suggested that this phosphorylation was induced by CCR7 activation. At the same time, the role of CCR7 in B1 integrin activation was also blocked by RGD-peptide indicating that CCR7 can activate $\beta 1$ integrin via CCR7- 31 integrin pathway.

CCR7 and $\beta 1$ integrin expressed by immunohistochemical staining had significant positive correlation in tumor tissues and metastatic lymph nodes. By using immunohistochemistry, we investigated the location of CCR7 and B1 integrin in SCCHN tumor tissues, metastatic lymph nodes, normal lymph nodes and oral mucosal tissues. CCR7 and B1 integrin were both found in the cell membrane and cytoplasm, mainly expressed in the surrounding of stroma in tumors cells and metastatic lymph node cells. Analysing the sections of CCR7 and 31 integrin staining in normal lymph nodes and oral mucosal tissues, we observed that the number of stained cells were low and that they were not expressed (Fig. 5 and Table I). The expression of CCR7 and $B 1$ integrin were both significantly correlated with cervical lymph node metastasis and SCCHN clinical stage $(\mathrm{P}<0.05)$. In addition, 


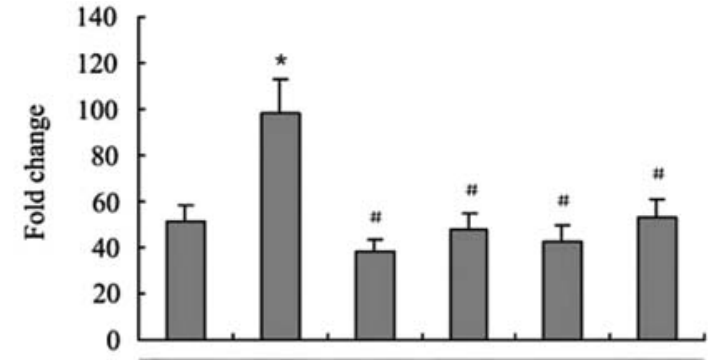

\begin{tabular}{|c|c|c|c|c|c|c|}
\hline$\beta 1$ integrin & $=$ & 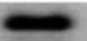 & 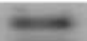 & $=$ & $2=$ & $=$ \\
\hline$\beta$-actin & 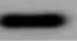 & $m$ & $m$ & $=$ & $m$ & $=$ \\
\hline CCL19 & - & + & - & + & - & + \\
\hline $\mathrm{CCR} 7 \mathrm{mAb}$ & - & - & + & + & - & - \\
\hline RGD & - & - & - & - & + & + \\
\hline
\end{tabular}

Figure 4. Western blot analysis of $B 1$ integrin expression in PCI-37B in vitro. PCI-37B cells were treated with and without the inhibitors RGD-peptide $(100 \mu \mathrm{g} / \mathrm{ml})$ and CCR7 $\mathrm{mAb}(10 \mu \mathrm{g} / \mathrm{ml})$ for $4 \mathrm{~h}$ at $37^{\circ} \mathrm{C}$, followed by CCL19 $(200 \mathrm{ng} / \mathrm{ml})$ at $37^{\circ} \mathrm{C}$ for $1 \mathrm{~h}$. CCR7 induces $\beta 1$ integrin expression, which is blocked by CCR7mAb and RGD-peptide inhibitors. The results are representative of three independent experiments. Relative expression to $B$-actin is shown as mean $\pm \mathrm{SD}\left({ }^{*} \mathrm{P}<0.05\right.$ compared to untreated group, ${ }^{\#} \mathrm{P}<0.05$ compared with the CCL19 group).

the T3/T4 tumor size also seems to express high levels of $B 1$ integrin $(\mathrm{P}<0.05)$. However, there were no significant differences between CCR7 or B1 integrin expression and age or gender $(\mathrm{P}>0.05)$. A moderate correlation was observed between CCR7 and 31 integrin expression in SCCHN tumor tissues (Spearman $\mathrm{r}=0.541, \mathrm{P}<0.05)$ and metastatic lymph nodes (Spearman $\mathrm{r}=0.496, \mathrm{P}<0.05$ ), but there was no significant correlation in normal lymph nodes (Spearman $\mathrm{r}=0.277, \mathrm{P}>0.05)$ and normal oral mucosal tissues (Spearman $\mathrm{r}=0.183, \mathrm{P}>0.05$ ).

\section{Discussion}

CCR7 has been shown to interact with chemokines (CCL19, CCL21), then modulate tumor cell migration, invasion and proliferation of metastatic SCCHN $(9,10,18)$. However, the mechanisms of adhesion and migration and the signaling pathway involved remains poorly understood. We have identified that CCR7 regulate cell adhesion and migration via B1 integrin in metastatic squamous cell carcinoma of the head and neck.

Metastasis involves the separation from the primary tumor, migration into the extracellular matrix, blood vessel invasion, adhesion to endothelium and extravasation and growth in a secondary organ (19). Integrins play roles in each step of this metastatic cascade, and sustain cell survival and interaction in target organs. Migration of tumor cells into the ECM and adhesion to the endothelium are essential events in the formation of metastases. During these steps, ß1 integrins activate focal adhesion kinase (FAK) to mediate cell-cell adhesion or cell-ECM adhesion, and affect signal transduction, cell proliferation, differentiation, survival and apoptosis (20). The signals which integrins transmit exert a stringent control on cell survival and cell proliferation, as well as imparting polarity to the cell and organizing and remodeling its cytoskeleton during adhesion and migration of many carcinoma cells (21).

CCR7 and integrin family are a series of molecules on the surface of cell membranes, signal transduction through these leads to activation of $\mathrm{G}$ proteins and phospholipase $\mathrm{C}$ and the elevation of cytosolic free calcium. CCL21 induced
A

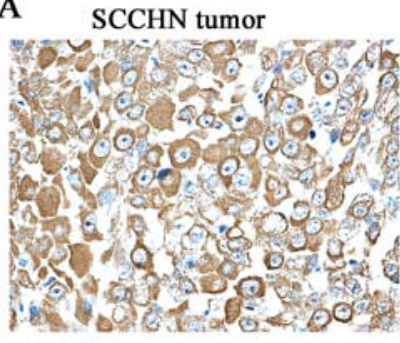

B

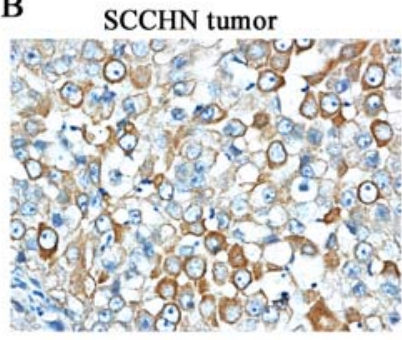

Normal oral mucosal
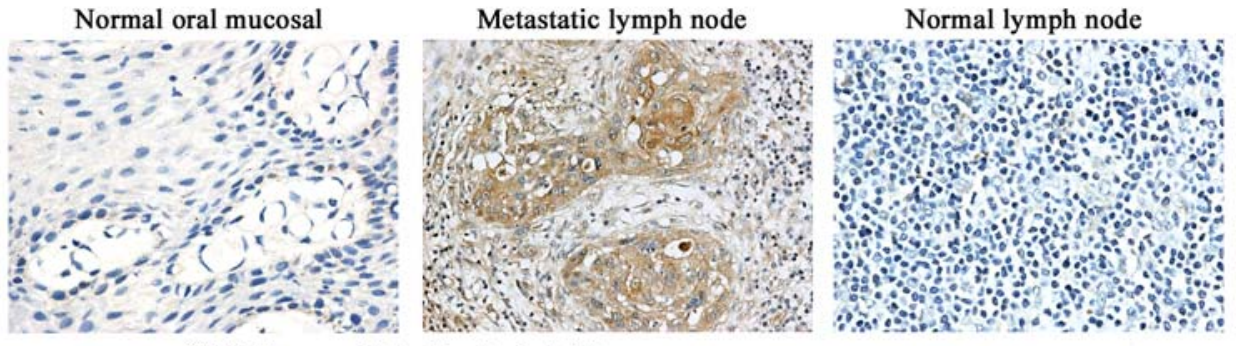

CCR7 immunohistochemical staining

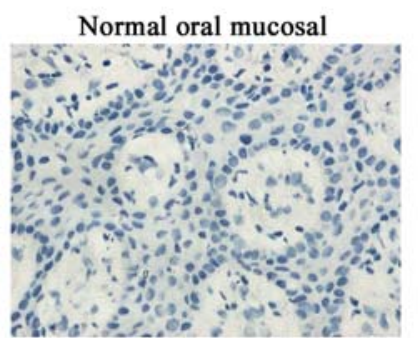

Metastatic lymph node
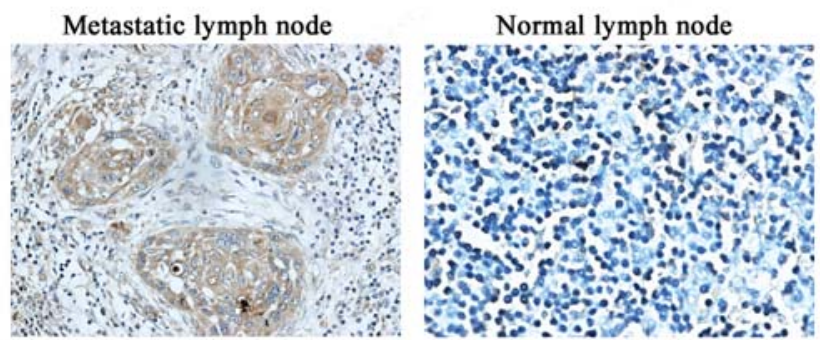

$\beta 1$ integrin immunohistochemical staining

Figure 5. Immunohistochemical staining shows CCR7 and B1 integrin with significant positive correlation in tumor tissues and metastatic lymph nodes. SCCHN tumor tissues [(original magnification (o.m.), x200)], metastatic lymph nodes (o.m., x100), normal lymph nodes (o.m., x200), and 10 normal human oral mucosal tissues (o.m., x200) show immunoreactivity for CCR7 (A) and B1 integrin (B). CCR7 immunoreactivity was observed mainly in the cell membrane and cytoplasm of tumor cells, conforming with $\beta 1$ integrin immunoreactivity. CCR7 and $\beta 1$ integrin expressed in normal lymph nodes and normal human oral mucosal tissues were weak or absent. 
Table I. Correlations between CCR7, B1 integrin expression and clinicopathological factors of SCCHN.

\begin{tabular}{|c|c|c|c|c|c|c|c|}
\hline \multirow{2}{*}{$\begin{array}{l}\text { Clinicopathological } \\
\text { characteristics }\end{array}$} & \multirow[b]{2}{*}{ No. of cases } & \multicolumn{2}{|c|}{ CCR7 } & \multirow{2}{*}{$\begin{array}{l}\text { Statistical } \\
\text { analysis }\end{array}$} & \multicolumn{2}{|c|}{$\beta 1$ integrin } & \multirow{2}{*}{$\begin{array}{l}\text { Statistical } \\
\text { analysis }\end{array}$} \\
\hline & & +-+++ & - & & +-+++ & - & \\
\hline \multicolumn{8}{|l|}{ Age } \\
\hline$\geq 60$ & 40 & 25 & 15 & $\chi^{2}=0.032$ & 22 & 18 & $\chi^{2}=0.410$ \\
\hline$<60$ & 38 & 23 & 15 & & 18 & 20 & \\
\hline \multicolumn{8}{|l|}{ Gender } \\
\hline Male & 50 & 32 & 18 & $\chi^{2}=0.357$ & 24 & 26 & $\chi^{2}=1.849$ \\
\hline Female & 28 & 16 & 12 & & 9 & 19 & \\
\hline \multicolumn{8}{|l|}{ Tumor size } \\
\hline $\mathrm{T} 1, \mathrm{~T} 2$ & 65 & 37 & 28 & $\chi^{2}=3.510$ & 25 & 40 & $\chi^{2}=6.478^{\mathrm{a}}$ \\
\hline $\mathrm{T} 3, \mathrm{~T} 4$ & 13 & 11 & 2 & & 10 & 3 & \\
\hline \multicolumn{8}{|l|}{ Clinical stage } \\
\hline I, II & 37 & 15 & 22 & $\chi^{2}=13.113^{\mathrm{a}}$ & 7 & 30 & $\chi^{2}=19.166^{\mathrm{a}}$ \\
\hline III, IV & 41 & 33 & 8 & & 28 & 13 & \\
\hline \multicolumn{8}{|l|}{ Nodal metastasis } \\
\hline Yes & 37 & 29 & 8 & $\chi^{2}=8.434^{\mathrm{a}}$ & 24 & 13 & $\chi^{2}=16.534^{\mathrm{a}}$ \\
\hline No & 41 & 19 & 22 & & 8 & 33 & \\
\hline
\end{tabular}

$\mathrm{P}<0.05$ (the internal difference of CCR7 or $\beta 1$ integrin expression within clinicopathological characteristics).

the adhesion of non-small lung cancer cells to vascular cell adhesion molecule-1 (VCAM-1) via activation of the $\alpha 4 \beta 1$ integrin through a $\mathrm{G}$ protein-coupled receptor (14). Since $\beta 1$ integrin has been suggested to play a crucial role in mediating the adhesion and arrest of other cell types at the endothelial vessels of lymph nodes, this change also supports a putative invasive phenotype induced by CCR7 activation on thyroid carcinoma cells (17), ovarian cancer cells (22) and other carcinoma cells $(13,14,18)$. During recent studies, $\beta 1$ integrin can be activated by some members of chemokine family, such as CCR9 (ligand is CCL25) $(23,24)$, CXCR4 (ligand is CXCL12) (13), but research relating to CCR7 (ligands are CCL19 and CCL21) is scarce, especially in SCCHN. Our results have shown that stimulation of CCL19 could also result in increased adhesion and migration of SCCHN cells. CCR7 induced the activation of $\beta 1$ integrin, then $B 1$ integrin interacted with its counterpart molecules, such as intercellular adhesion molecule-1 (ICAM-1), VCAM1 and mucosal address in cellular adhesion molecule-1 (MadCAM-1). As has previously been reported, we found that when $B 1$ integrin were inhibited, the CCL19-induced adhesion and migration of SCCHN cells were also inhibited.

Organ selectivity of cancer metastasis is regulated not only by cancer migration but also its adhesion at the target organs of cancer metastasis (25). It has been reported that this integrin-mediated adhesion was induced by CCL2 1 (CCR7' ligand) and that the adhesion regulated the migration of lymphocytes to the lymph node (26). In this study, we used MTT assays and transwell migration assays to examine CCL19-induced activation of $\beta 1$ integrin that significantly enhanced the adhesion (Fig. 1) and migration (Fig. 2) index in SCCHN, and was blocked by $\beta 1$ integrin inhibitor RGD peptide. Thus, supporting the hypothesis that CCL19 concentrations in the lymph nodes probably induce SCCHN cell migration into these organs through a CCR7-mediated mechanism. High levels of actin polymerization are required for the formation of pseudopodia, which are needed for chemokine mediated cell migration and invasion into surrounding tissues and efficient metastasis formation (27). In our study (Fig. 3), we examined rhodamine-labelled phalloidin staining by inverted microscope, and observed reorganization of the actin cytoskeleton of PCI-37B was enhanced in response to CCL19, and this function inhibited by RGD peptide. Furthermore, our results (Fig. 4) show that stimulation of CCL19 could also result in increased phosphorylation of B1 integrin in Western blot analysis, conforming with previous research (15). CCR7 and $\beta 1$ integrin were highly expressed in various tumors $(5,7,17,28)$, and our results from the 78 cases were consistent with previous studies. Immunohistochemical studies confirmed the presence of CCR7 and B1 integrin in the cytoplasm and cell membrane of SCCHN tumor tissues, metastatic lymph nodes, and all significantly correlated with cervical lymph node metastasis and clinical stage, but in normal lymph nodes and oral mucosal tissues they were low or absent. CCR7 was reported to be a novel prediction biomarker of metastasis in cancer. Future studies including the immunohistochemical analysis of both CCR7 and integrin might be useful to predict lymph node metastasis (19). Therefore, we suggest that CCR7 activation by CCL19 via $\beta 1$ integrin may promote SCCHN 
cell actin polymerization, cell adhesion molecule modulation and cell migration.

In conclusion, our study suggests that CCR7 regulates not only migration but also the adhesion of metastatic SCCHN via $\beta 1$ integrin. Therefore, CCR7 and $\beta 1$ integrin might be targeting molecules for SCCHN therapy of metastasis to lymph nodes. Although we believe that this finding is important for identifying it, further studies are needed to determine why and how CCR7 trigged $\beta 1$ integrin and further experiments should elucidate whether this is a unique or ubiquitous phenomenon. It is therefore impossible to cure the tumor by blocking only the CCR7-ß1 integrin pathway. However, it provides us with a new idea that we may be able to improve prognosis by blocking CCR7- $\$ 1$ integrin as it cooperates with other factors in adjuvant chemotherapy. Thus, further work should be done.

\section{Acknowledgements}

We grateful acknowledge the University of Pittsburgh Cancer Institute, USA, for supplying the cell line PCI-37B. This research was supported by grant from the National Natural Science Foundation of China (No. 30672331) and Foundation of Education Bureau of Liaoning Province, China (No. 2009A755).

\section{References}

1. Yoon Y, Liang Z, Zhang X, Choe M, Zhu A, Cho HT, Shin DM, Goodman MM, Chen ZG and Shim H: CXC chemokine receptor-4 antagonist blocks both growth of primary tumor and metastasis of head and neck cancer in xenograft mouse models. Cancer Res 67: 7518-7524, 2007

2. Younes MN, Yigitbasi OG, Yazici YD, Jasser SA, Bucana CD, El-Naggar AK, Mills GB and Myers JN: Effects of the integrinlinked kinase inhibitor QLT0267 on squamous cell carcinoma of the head and neck. Arch Otolaryngol Head Neck Surg 133: 15-23, 2007

3. Onoé K and Yanagawa Y: CCL19 induces rapid dendritic extension of murine dendritic cells. Blood 100: 1948-1956 2002.

4. Nagira M, Imai T, Yoshida R, Takagi S, Iwasaki M, Baba M, Tabira Y, Akagi J, Nomiyama H and Yoshie O: A lymphocytespecific CC chemokine, secondary lymphoid tissue chemokine (SLC), is a highly efficient chemoattractant for B cells and activated T cells. Eur J Immunol 28: 1516-1523, 1998.

5. Takanami I: Overexpression of CCR7 mRNA in non-small cell lung cancer: correlation with lymph node metastasis. Int J Cancer 105: 186-189, 2003.

6. Zlotnik A: Chemokines and cancer. Int J Cancer 119: 2026-2029, 2006.

7. Arigami T, Natsugoe S, Uenosono Y, Yanagita S, Arima H, Hirata M, Ishigami S and Aikou T: CCR7 and CXCR4 expression predicts lymph node status including micrometastasis in gastric cancer. Int J Oncol 35: 19-24, 2009.

8. Günther K, Leier J, Henning G, Dimmler A, Weissbach R, Hohenberger W and Förster R: Prediction of lymph node metastasis in colorectal carcinoma by expression of chemokine receptor CCR7. Int J Cancer 116: 726-733, 2005.

9. Liu FY, Zhao ZJ, Li P, Ding X, Zong ZH and Sun CF. Mammalian target of rapamycin (mTOR) is involved in the survival of cells mediated by chemokine receptor 7 through $\mathrm{PI} 3 \mathrm{~K} / \mathrm{Akt}$ in metastatic squamous cell carcinoma of the head and neck. Br J Oral Maxillofac Surg 48: 291-296, 2010.

10. Zhao ZJ, Liu FY and Sun CF: Effect of chemokine receptor 7 small interfering RNA on proliferation and invasion of squamous cell carcinoma of head and neck. Zhonghua Kou Qiang Yi Xue Za Zhi 44: 5-10, 2009.
11. Müller A, Homey B, Soto H, Ge N, Catron D, Buchanan ME, McClanahan T, Murphy E, Yuan W, Wagner SN, Barrera JL, Mohar A, Verástegui E and Zlotnik A: Involvement of chemokine receptors in breast cancer metastasis. Nature 410: 50-56, 2001 .

12. Constantin G, Majeed M, Giagulli C, Piccio L, Kim JY, Butcher EC and Laudanna C: Chemokines trigger immediate B2 integrin affinity and mobility changes: differential regulation and roles in lymphocyte arrest under flow. Immunity13: 759-769, 2000 .

13. Jones J, Marian D, Weich E, Engl T, Wedel S, Relja B, Jonas D and Blaheta RA: CXCR4 chemokine receptor engagement modifies integrin dependent adhesion of renal carcinoma cells. Exp Cell Res 313: 4051-4065, 2007.

14. Koizumi K, Kozawa Y, Ohashi Y, Nakamura ES, Aozuka Y, Sakurai H, Ichiki K, Doki Y, Misaki T and Saiki I: CCL21 promotes the migration and adhesion of highly lymph node metastatic human non-small cell lung cancer Lu-99 in vitro. Oncol Rep 17: 1511-1516, 2007.

15. Banas B, Wörnle M, Merkle M, Gonzalez-Rubio M, Schmid H, Kretzler M, Pietrzyk MC, Fink M, Perez de Lema G and Schlöndorff D: Binding of the chemokine SLC/CCL21 to its receptor CCR7 increases adhesive properties of human mesangial cells. Kidney Int 66: 2256-2263, 2004.

16. Till KJ, Lin K, Zuzel M and Cawley JC: The chemokine receptor CCR7 and a4 integrin are important for migration of chronic lymphocytic leukemia cells into lymph nodes. Blood 99: 2977-2984, 2002.

17. Sancho M, Vieira JM, Casalou C, Mesquita M, Pereira T, Cavaco BM, Dias S and Leite V: Expression and function of the chemokine receptor CCR7 in thyroid carcinomas. J Endocrinol 191: 229-238, 2006.

18. Wang J, Zhang X, Thomas SM, Grandis JR, Wells A, Chen ZG and Ferris RL: Chemokine receptor 7 activates phosphoinositide-3 kinase-mediated invasive and prosurvival pathways in head and neck cancer cells independent of EGFR. Oncogene 24: 5897-5904, 2005.

19. Liotta LA, Steeg PS and Stetler-Stevenson WG: Cancer metastasis and angiogenesis: an imbalance of positive and negative regulation. Cell 64: 327-336, 1991.

20. Brenner W, Greber I, Gudejko-Thiel J, Beitz S, Schneider E, Walenta S, Peters K, Unger R and Thüroff JW: Migration of renal carcinoma cells is dependent on protein kinase Cdelta via betal integrin and focal adhesion kinase. Int $\mathrm{J}$ Oncol 32: 1125-1131, 2008.

21. Giancotti FG and Ruoslahti E: Integrin signaling. Science 285: 1028-1032, 1999.

22. Moschos SJ, Drogowski LM, Reppert SL and Kirkwood J: Integrins and cancer. Oncology 21: 13-20, 2007.

23. Scotton CJ, Wilson JL, Milliken D, Stamp G and Balkwill FR: Epithelial cancer cell migration: a role for chemokine receptors? Cancer Res 61: 4961-4965, 2001.

24. Parmo-Cabañas M, García-Bernal D, García-Verdugo R, Kremer L, Márquez $\mathrm{G}$ and Teixidó J: Intracellular signaling required for CCL25-stimulated $\mathrm{T}$ cell adhesion mediated by the integrin $\alpha 4 \beta 1$. J Leukoc Biol 82: 380-391, 2007.

25. Gunn MD, Tangemann K, Tam C, Cyster JG, Rosen SD and Williams LT: A chemokine expressed in lymphoid high endothelial venules promotes the adhesion and chemotaxis of naïve T lymphocytes. Proc Natl Acad Sci USA 95: 258-263, 1998.

26. Nicolson GL: Organ specificity of tumor metastasis: role of preferential adhesion, invasion and growth of malignant cells at specific secondary sites. Cancer Metastasis Rev 7: 143-188, 1988.

27. Van Haastert PJ and Devreotes PN: Chemotaxis: signalling the way forward. Nat Rev Mol Cell Biol 5: 626-634, 2004.

28. Kasono K, Blackwell JL, Douglas JT, Dmitriev I, Strong TV, Reynolds P, Kropf DA, Carroll WR, Peters GE, Bucy RP, Curiel DT and Krasnykh V: Selective gene delivery to head and neck cancer cells via an integrin targeted adenoviral vector. Clin Cancer Res 5: 2571-2579, 1999. 